\title{
Article \\ Citral-Containing Essential Oils as Potential Tyrosinase Inhibitors: A Bio-Guided Fractionation Approach
}

\author{
Francesca Capetti ${ }^{1,+} \mathbb{D}$, Massimo Tacchini ${ }^{2,+} \mathbb{D}$, Arianna Marengo ${ }^{1}$, Cecilia Cagliero ${ }^{1} \mathbb{D}$, Carlo Bicchi $^{1} \mathbb{D}^{\mathbb{D}}$, \\ Patrizia Rubiolo ${ }^{1}$ (D) and Barbara Sgorbini ${ }^{1, *(D)}$
}

1 Dipartimento di Scienza e Tecnologia del Farmaco, Università degli Studi di Torino, Via Pietro Giuria 9, I-10125 Turin, Italy; francesca.capetti@unito.it (F.C.); arianna.marengo@unito.it (A.M.); cecilia.cagliero@unito.it (C.C.); carlo.bicchi@unito.it (C.B.); patrizia.rubiolo@unito.it (P.R.)

2 Dipartimento di Scienze della vita e Biotecnologie, Università degli Studi di Ferrara, Via L. Borsari 46, I-44121 Ferrara, Italy; massimo.tacchini@unife.it

* Correspondence: barbara.sgorbini@unito.it; Tel.: +39-011-670-7135

+ These authors contributed equally to the work.

Citation: Capetti, F.; Tacchini, M.; Marengo, A.; Cagliero, C.; Bicchi, C.; Rubiolo, P.; Sgorbini, B.

Citral-Containing Essential Oils as

Potential Tyrosinase Inhibitors: A Bio-Guided Fractionation Approach. Plants 2021, 10, 969. https://doi.org/ 10.3390/plants10050969

Academic Editors: Alessandra Braca, Marinella De Leo and Daniela Rigano

Received: 15 April 2021

Accepted: 9 May 2021

Published: 13 May 2021

Publisher's Note: MDPI stays neutral with regard to jurisdictional claims in published maps and institutional affiliations.

Copyright: (C) 2021 by the authors. Licensee MDPI, Basel, Switzerland. This article is an open access article distributed under the terms and conditions of the Creative Commons Attribution (CC BY) license (https:/ / creativecommons.org/licenses/by/ $4.0 /)$.

\begin{abstract}
Excessive melanin production causes serious dermatological conditions as well as minor aesthetic problems (i.e., freckles and solar lentigo). The downregulation of tyrosinase is a widespread approach for the treatment of such disorders, and plant extracts have often proven to be valuable sources of tyrosinase inhibitors. Citral (a mixture of neral and geranial) is an important fragrance ingredient that has shown anti-tyrosinase potential. It is highly concentrated in the essential oils (EOs) of Cymbopogon schoenanthus (L.) Spreng., Litsea cubeba (Lour.) Pers., Melissa officinalis L., and Verbena officinalis L. However, only L. cubeba $\mathrm{EO}$ has been investigated for use as a potential skin-whitening agent. This work evaluates the in vitro tyrosinase inhibitory activity of these EOs and studies, using bio-assay oriented fractionation, whether their differing chemical compositions influence the overall EO inhibitory activities via possible synergistic, additive, and/or competitive interactions between EOs components. The inhibitory activity of $C$. schoenanthus EO and that of M. officinalis EOs, with negligible (+)-citronellal amounts, were in-line with their citral content. On the other hand, L. cubeba and $V$. officinalis EOs inhibited tyrosinase to considerably greater extents as they contained $\beta$-myrcene, which contributed to the overall EO activities. Similar observations were made for M. officinalis EO, which bears high (+)-citronellal content which increased citral activity.
\end{abstract}

Keywords: tyrosinase inhibition; essential oils; citral

\section{Introduction}

Tyrosinase is the key enzyme in the biosynthesis of melanin pigments in several bacteria, fungi, plants, animals, and humans. In humans, tyrosinase catalyzes the rate limiting steps in the melanin biosynthetic pathway. This biosynthesis is characterized by several enzymatic and chemical reactions that lead to melanin formation from the amino acid L-tyrosine, with tyrosinase catalyzing its hydroxylation to $o$-dopaquinone via its monophenolase and diphenolase activities. Although there are other enzymes involved in melanogenesis, only the tyrosinase-catalyzed reactions cannot occur spontaneously, whereas the remaining steps can proceed without enzyme activity at physiological pH [1]. For this reason, tyrosinase downregulation is a very widespread approach to the reduction of excessive melanin production, and the use of tyrosinase inhibitors as skin-whitening agents has demonstrated significant clinical and cosmetic prominence [2].

In the EU market, the tyrosinase inhibitors that are employed as skin-whitening agents can be grouped into two main categories: those banned under EU cosmetic regulation 1223/2009 (i.e., hydroquinone and monobenzyl ether hydroquinone) due to their severe side effects, but that are still used to treat hyperpigmentation under medical supervision; and tyrosinase inhibitors that are permitted for use in cosmetics products (i.e., arbutin, 
aloesin, kojic acid) [2,3]. This second group, however, is still characterized by potentially significant side-effects; clinical studies on kojic acid have indeed highlighted cases of erythema, stinging sensations, and contact eczema after application. Similarly, the European Scientific Committee on Consumer Safety has raised concerns regarding the use of arbutin as a cosmetic ingredient [2], due to the potential hydrolysis of its glyosidic bond that releases hydroquinone. There is therefore a need for novel molecule templates and/or mixtures of bioactive compounds to treat hyperpigmentation.

Plants have been valuable sources of skin-whitening agents, and three out of five of the most employed agents, both medically and cosmetically, are plant specialized metabolites (i.e., hydroquinone, $\beta$-arbutin, aloesin). To date, phenolic compounds have principally been investigated as potential tyrosinase inhibitors, and these include flavonoids (e.g., quercetin [4]), stilbenes (e.g., resveratrol [1]), phenylpropanoids (e.g., cinnamaldehyde [5] and eugenol [6]), and phenolic acids (e.g., anisic acid and benzoic acid [7]). The interest for terpenoids has been considerably lower and they have relatively been under-investigated as anti-tyrosinase agents.

Citral is among the limited number of terpenoid derivatives with anti-tyrosinase properties that have been studied. It is a mixture of two isomers, cis- and trans-3,7-dimethyl-2,6octadienal (i.e., neral and geranial), which have been proven to block the in vitro enzymatic activity of mushroom tyrosinase [8]. In addition to its importance as odorous ingredient in beverages, foods, and cosmetics, citral has shown promising in vitro biological activities including anti-fungal, anti-bacterial, antioxidant, and anti-inflammatory effects [9-11]. Moreover, recent studies have highlighted that citral has potential therapeutic significance as a smooth muscle relaxer and local anesthetic, as it promotes relaxation in tracheal, uterine, and aortic smooth muscles and inhibits nerve excitability in animal models [12-15].

Citral is obtained from the essential oils (EOs) of several botanical species, including Cymbopogon schoenanthus (L.) Spreng., Litsea cubeba (Lour.) Pers., Melissa officinalis L., and Verbena officinalis L. To the best of the authors' knowledge, only L. cubeba $\mathrm{EO}$ has been investigated for its tyrosinase inhibitory activity [16]. Therefore, this study aims to evaluate the tyrosinase inhibitory activities of C. schoenanthus, L. cubeba, M. officinalis, and V. officinalis EOs, using an in vitro colorimetric assay, to assess whether the different chemical compositions influence the overall EO inhibitory activities via any possible synergistic, additive and/or competitive interactions between their components. This study uses a bioassay-guided fractionation approach to evaluate comprehensively the EOs constituents and their enantiomers, when chiral, that contribute to the EO inhibitory activity against a mushroom source of tyrosinase, which is a good model system for the preliminary screening of tyrosinase inhibitors [17].

\section{Results and Discussion}

\subsection{Chemical Composition and Citral Content of the Investigated Essential Oils}

In our attempt to comprehensively characterize all of the potential EO components that contribute to the considered biological activity, the investigated EOs were analyzed by GC, with both FID and MS detection. The normalized relative percentage abundances (calculated from the absolute areas normalized to the internal standard C13 by using response factors $[18,19])$ of all the detected compounds were determined and used to compare EO compositions. Figure 1 reports the GC-MS profile of the investigated EOs analysed with a conventional column. Table 1 lists, for each investigated EO, the compounds that displayed a normalized percentage abundance above 0.1 , while the complete EO chemical compositions are reported in the Supplementary Materials (Tables S1-S5).

All of the investigated EOs are rich in neral (cis-3,7-dimethyl-2,6-octadienal) and geranial (trans-3,7-dimethyl-2,6-octadienal), which are the most abundant compounds. The neral/ geranial ratio was very similar in all the investigated EOs and corresponded to $0.74 \pm 0.05$. The $C$. schoenanthus and L. cubeba EOs display the highest neral and geranial content, which accounts for, on average, $60 \%$ of their entire EO compositions, and which is 1.5-times greater than in V. officinalis EO and in the three M. officinalis EOs (i.e., Sample 
1,2 , and 3). The additional oxygenated compounds that are common to all the EOs are 6-methyl-5-hepten-1-one, linalool and citronellal. The latter is significantly more abundant in the M. officinalis EO 1 than in the other investigated EOs, including the M. officinalis EO 2 and 3.

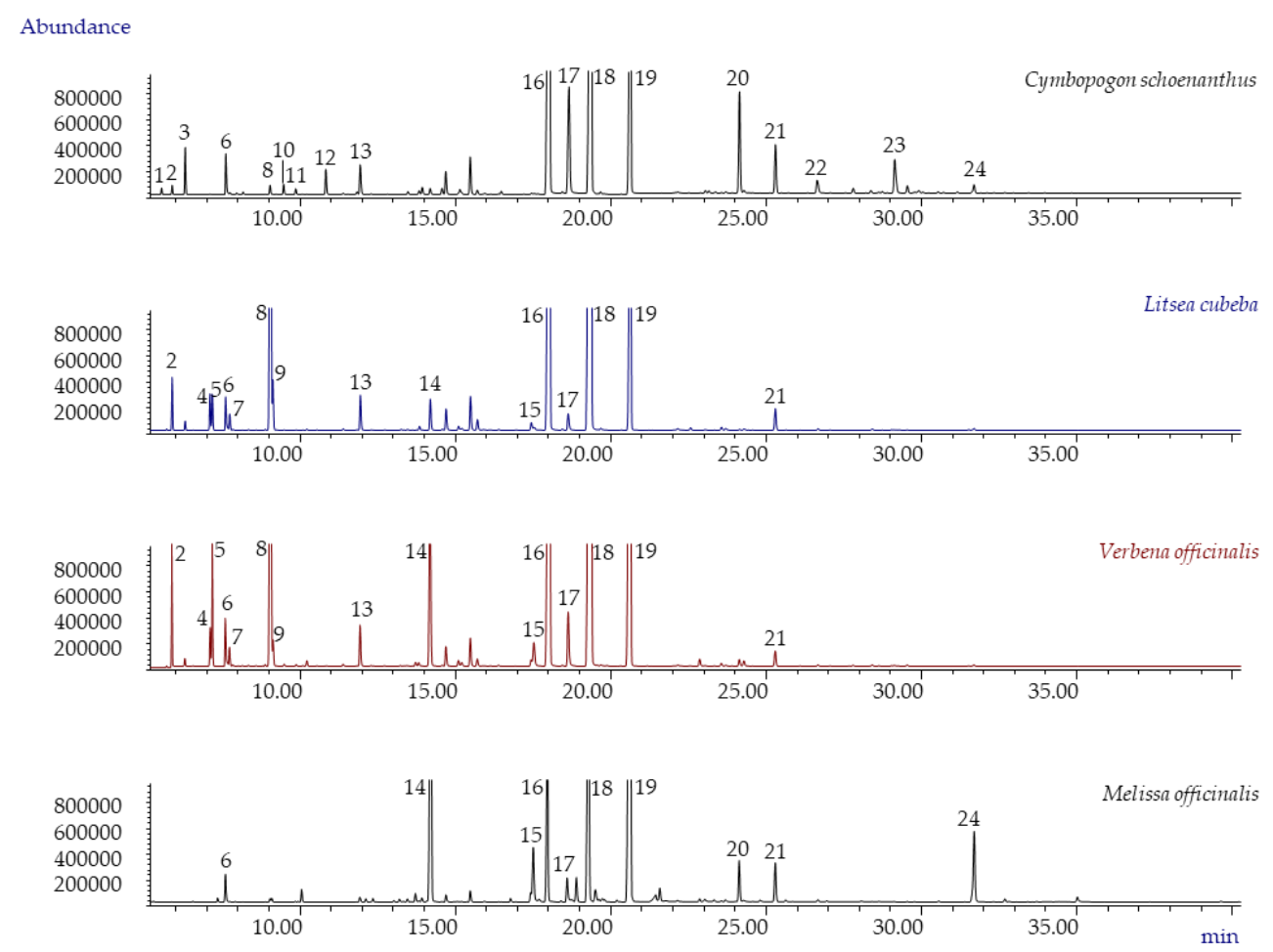

Figure 1. GC-MS profiles of Cymbopogon schoenanthus (batch 2020), Litsea cubeba (batch 2020), Verbena officinalis (batch 2020), and Melissa officinalis 1 essential oils. Legend: (1) tricyclene, (2) $\alpha$-pinene, (3) camphene, (4) sabinene, (5) $\beta$-pinene, (6) 6-methyl-5-hepten-2-one, (7) $\beta$-myrcene, (8) limonene, (9) 1,8-cineole, (10) cis- $\beta$-ocimene, (11) trans- $\beta$-ocimene, (12) 4-nonanone, (13) linalool, (14) citronellal, (15) nerol, (16) neral, (17) geraniol, (18) geranial, (19) ISTD (C13), (20) geranyl acetate, (21) trans$\beta$-caryophyllene, (22) trans-isoeugenol, (23) $\gamma$-cadinene, (24) caryophyllene oxide. For analysis conditions, see Section 3.4.

The abundance of the hydrocarbon fraction varies significantly in the different EOs. M. officinalis EO 1 contains only trans- $\beta$-caryophyllene and $\alpha$-humulene as sesquiterpene hydrocarbons, which account for $2.7 \%$ and $0.13 \%$ of the total EO, respectively. The C. schoenanthus EO presents a slightly richer hydrocarbon fraction than $M$. officinalis EO 1 (i.e., $7.0 \%$ ), containing both monoterpenes (i.e., camphene, cis- $\beta$-ocimene, limonene, $\alpha$-pinene, trans- $\beta$-ocimene, $\alpha$-thujene) and sesquiterpenes (i.e., trans- $\beta$-caryophyllene, $\gamma$-cadinene, $\delta$-cadinene, germacrene $\mathrm{D}, \beta$-elemene) in moderate amounts. In the L. cubeba and $V$. officinalis EOs, the hydrocarbon fraction accounts for $20 \%$ of the total $\mathrm{EO}$ and limonene is the most abundant compound (i.e., 15.0 and 10.9\%, respectively), followed by $\alpha$-pinene, $\beta$ pinene, sabinene, trans- $\beta$-caryophyllene, $\beta$-myrcene, camphene, and $\alpha$-copaene. Finally, $M$. officinalis EO 2 and 3 are characterized by the highest hydrocarbon fraction content (38.8\% and $31.8 \%$ of the total EO, respectively). In both samples, the hydrocarbon fraction mainly contains sesquiterpenes, namely trans- $\beta$-caryophyllene (27.8\% and $20.0 \%$, respectively), and $\alpha$-humulene $(3.0 \%$ and $2.6 \%)$, and a reduced monoterpene fraction that is mainly characterized by limonene $(4.2 \%$ and $3.2 \%$, respectively). 


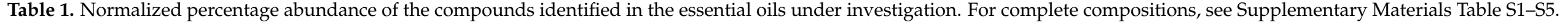

\begin{tabular}{|c|c|c|c|c|c|c|c|c|c|c|c|c|c|c|}
\hline \multirow[b]{2}{*}{ Compound } & \multirow[b]{2}{*}{$I^{t} s_{\exp }$} & \multirow[b]{2}{*}{$\mathbf{I}^{\mathbf{t}} \mathbf{s}_{\text {lit }}$} & \multicolumn{2}{|c|}{ C. schoenanthus } & \multicolumn{2}{|l|}{ L. cubeba } & \multicolumn{2}{|c|}{ V. officinalis } & \multicolumn{2}{|c|}{ M. officinalis ${ }_{1}$} & \multicolumn{2}{|c|}{ M. officinalis $_{2}$} & \multicolumn{2}{|c|}{ M. officinalis 3} \\
\hline & & & $\begin{array}{l}\text { Norm. Rel. \% } \\
\text { Abundance * }\end{array}$ & $\mathrm{CV}$ & $\begin{array}{l}\text { Norm. Rel. \% } \\
\text { Abundance * }\end{array}$ & $\mathrm{CV}$ & $\begin{array}{l}\text { Norm. Rel. \% } \\
\text { Abundance * }\end{array}$ & $\mathrm{CV}$ & $\begin{array}{l}\text { Norm. Rel. \% } \\
\text { Abundance }\end{array}$ & $\mathrm{CV}$ & $\begin{array}{l}\text { Norm. Rel. \% } \\
\text { Abundance }\end{array}$ & $\mathrm{CV}$ & $\begin{array}{l}\text { Norm. Rel. \% } \\
\text { Abundance }\end{array}$ & $\mathrm{CV}$ \\
\hline Tricyclene & 926 & 930 & & & & & & & & & & & 0.11 & 2.5 \\
\hline$\alpha$-Thujene & 930 & 931 & 0.15 & 11.7 & & & & & & & & & & \\
\hline$\alpha$-Pinene & 941 & 939 & 0.22 & 8.4 & 1.3 & 0.6 & 3.7 & 1.2 & & & 0.43 & 1.2 & 0.40 & 3.9 \\
\hline Camphene & 954 & 953 & 1.2 & 4.2 & 0.26 & 0.4 & 0.22 & 1.9 & & & 0.31 & 0.7 & 0.95 & 2.6 \\
\hline Sabinene & 976 & 976 & & & 0.97 & 2.6 & 1.1 & 0.2 & & & 0.17 & 8.4 & 0.13 & 4.8 \\
\hline$\beta$-Pinene & 978 & 980 & & & 1.0 & 3.1 & 4.0 & 0.2 & & & 0.55 & 12.5 & 1.0 & 3.0 \\
\hline 1-Octen-3-ol & 982 & 978 & & & & & & & 0.21 & 4.4 & & & & \\
\hline$\beta$-Myrcene & 992 & 991 & & & 0.47 & 5.5 & 0.57 & 0.8 & & & 0.14 & 4.3 & & \\
\hline$p$-Cymene & 1026 & 1024 & & & & & & & & & 0.11 & 0.2 & & \\
\hline Limonene & 1029 & 1031 & 0.29 & 5.9 & 15.0 & 0.1 & 10.9 & 5.4 & & & 4.2 & 0.2 & 3.7 & 2.0 \\
\hline 1,8-Cineole & 1030 & 1033 & & & 1.5 & 0.1 & 0.78 & 6.0 & & & 0.91 & 0.1 & 0.34 & 2.5 \\
\hline cis- $\beta$-Ocimene & 1040 & 1040 & 0.31 & 5.0 & & & & & & & 0.71 & 0.1 & 0.07 & 2.0 \\
\hline trans- $\beta$-Ocimene & 1050 & 1050 & 0.19 & 0.6 & & & & & & & & & & \\
\hline$\gamma$-Terpinene & 1059 & 1062 & & & & & 0.20 & 1.4 & & & 0.29 & 2.0 & & \\
\hline$\alpha$-Terpinolene & 1086 & 1088 & & & & & & & & & & & & \\
\hline Linalool & 1098 & 1098 & 1.1 & 0.7 & 1.1 & 9.7 & 1.5 & 7.8 & 0.32 & 1.6 & 1.2 & 2.6 & 0.95 & 4.8 \\
\hline Nonal & 1098 & 1103 & & & & & & & 0.17 & 1.7 & & & & \\
\hline cis-Rose oxide & 1109 & 1111 & & & & & & & 0.20 & 0.3 & & & & \\
\hline Isopulegol & 1144 & 1146 & & & & & 0.14 & 3.1 & 0.52 & 2.8 & & & & \\
\hline Citronellal & 1155 & 1153 & 0.22 & 9.7 & 1.1 & 10.4 & 5.2 & 1.3 & 19.6 & 0.4 & 0.26 & 5.8 & 0.31 & 1.6 \\
\hline Borneol & 1163 & 1165 & 0.24 & 2.3 & & & & & & & & & & \\
\hline 4-Terpineol & 1175 & 1177 & & & 0.17 & 7.9 & 0.25 & 0.2 & & & & & 0.20 & 5.5 \\
\hline$\alpha$-terpineol & 1188 & 1189 & 0.18 & 1.0 & 0.40 & 9.5 & 0.32 & 8.7 & & & 0.22 & 1.5 & & \\
\hline Nerol & 1229 & 1228 & & & 0.32 & 10.6 & 0.25 & 4.5 & 0.45 & 3.9 & & & & \\
\hline trans- $\beta$-Citronellol & 1231 & 1228 & & & 0.13 & 3.6 & 1.2 & 0.5 & 4.1 & 0.7 & & & 0.11 & 1.8 \\
\hline Neral & 1243 & 1240 & 32.0 & 0.2 & 30.8 & 0.3 & 27.5 & 0.1 & 19.7 & 0.1 & 21.4 & 0.8 & 16.5 & 0.7 \\
\hline Piperitone & 1252 & 1252 & & & & & & & 0.10 & 2.8 & & & 0.17 & 1.4 \\
\hline Geraniol & 1257 & 1255 & 5.16 & 6.3 & 0.78 & 0.8 & 2.4 & 0.2 & 1.7 & 2.7 & 1.6 & 0.5 & 3.3 & 1.4 \\
\hline Methyl citronellate & 1263 & 1261 & & & & & & & 1.6 & 1.8 & & & & \\
\hline Geranial & 1274 & 1270 & 41.8 & 1.1 & 39.4 & 1.8 & 33.2 & 0.6 & 29.6 & 0.2 & 28.8 & 0.2 & 26.5 & 0.2 \\
\hline Citronellyl formate & 1275 & 1277 & & & & & & & 1.0 & 0.2 & & & 0.66 & 0.6 \\
\hline$\alpha$-Terpinyl acetate & 1348 & 1350 & & & 0.11 & 1.8 & & & & & & & & \\
\hline$\alpha$-Cubebene & 1351 & 1347 & & & & & & & & & 0.33 & 0.5 & 0.34 & 0.2 \\
\hline Methyl geranate & 1323 & 1324 & & & & & & & 0.86 & 1.6 & & & & \\
\hline Citronellyl acetate & 1355 & 1354 & & & & & 0.30 & 0.5 & 0.18 & 4.0 & & & & \\
\hline Neryl acetate & 1365 & 1366 & & & & & & & 0.13 & 0.53 & & & 0.26 & 2.3 \\
\hline$\alpha$-Copaene & 1371 & 1372 & & & 0.13 & 9.8 & 0.13 & 4.1 & & & 0.79 & 0.4 & 0.81 & 0.3 \\
\hline Geranyl acetate & 1384 & 1383 & 4.2 & 0.6 & & & 0.29 & 1.0 & 2.5 & 0.2 & 0.92 & 0.4 & 1.6 & 0.2 \\
\hline
\end{tabular}


Table 1. Cont.

\begin{tabular}{|c|c|c|c|c|c|c|c|c|c|c|c|c|c|c|}
\hline \multirow[b]{2}{*}{ Compound } & \multirow[b]{2}{*}{$I^{t} s_{\exp }$} & \multirow[b]{2}{*}{$\mathbf{I}^{\mathrm{t}} \mathbf{s}_{\text {lit }}$} & \multicolumn{2}{|c|}{ C. schoenanthus } & \multicolumn{2}{|l|}{ L. cubeba } & \multicolumn{2}{|c|}{ V. officinalis } & \multicolumn{2}{|c|}{ M. officinalis 1} & \multicolumn{2}{|c|}{ M. officinalis ${ }_{2}$} & \multicolumn{2}{|c|}{ M. officinalis ${ }_{3}$} \\
\hline & & & $\begin{array}{l}\text { Norm. Rel. \% } \\
\text { Abundance * }\end{array}$ & $\mathrm{CV}$ & $\begin{array}{l}\text { Norm. Rel. \% } \\
\text { Abundance * }\end{array}$ & $\mathrm{CV}$ & $\begin{array}{l}\text { Norm. Rel. \% } \\
\text { Abundance * }\end{array}$ & CV & $\begin{array}{l}\text { Norm. Rel. \% } \\
\text { Abundance }\end{array}$ & $\mathrm{CV}$ & $\begin{array}{l}\text { Norm. Rel. \% } \\
\text { Abundance }\end{array}$ & $\mathrm{CV}$ & $\begin{array}{l}\text { Norm. Rel. \% } \\
\text { Abundance }\end{array}$ & $\mathrm{CV}$ \\
\hline$\beta$-Elemene & 1388 & 1391 & 0.13 & 3.9 & & & 0.25 & 0.3 & & & 0.09 & 3.6 & 0.12 & 0.1 \\
\hline $\begin{array}{l}\text { trans-Isoeugenol } \\
\alpha \text {-Humulene }\end{array}$ & $\begin{array}{l}1447 \\
1454\end{array}$ & $\begin{array}{l}1450 \\
1447\end{array}$ & 0.71 & 4.4 & & & & & 3 & & & & & \\
\hline Germacrene D & 1475 & 1480 & 0.21 & 3.2 & & & & & 0.13 & 7.0 & 3.0 & 0.3 & 2.6 & 0.7 \\
\hline$\gamma$-Cadinene & 1508 & 1513 & 1.8 & 2.4 & & & & & & & 0.59 & 0.2 & 0.99 & 0.9 \\
\hline$\delta$-Cadinene & 1519 & 1524 & 0.32 & 1.2 & & & & & & & 0.52 & 2.0 & 0.81 & 2.3 \\
\hline
\end{tabular}

* Average values which were derived from the analyses of three EOs obtained from the same botanical species but of different years of production. $\mathrm{CV}$ : Coefficient of Variation $=($ Standard Deviation $/$ Mean $) \times 100$. 
Three samples of L. cubeba, $V$. officinalis, and C. schoenanthus Eos produced in different years as well as three samples of $M$. officinalis EOs from distinct manufactures were investigated. GC-MS analyses of C. schoenanthus, L. cubeba, M. officinalis, and V. officinalis did not reveal significant qualitative and quantitative differences in the chemical composition of the three samples of different years of production. This may be ascribed to optimal storage conditions, i.e., in an amber-glass container at $4{ }^{\circ} \mathrm{C}$ in the dark with a negligible head space. On the other hand, GC-MS analyses showed significant differences in the abundances of citronellal and trans- $\beta$-caryophyllene in the three investigated $M$. officinalis EOs. Citronellal amounted to $19.6 \%, 0.26 \%$, and $0.31 \%$ in the $M$. officinalis EO 1,2 , and 3, respectively. On the contrary, as previously described, trans- $\beta$-caryophyllene is considerably more abundant in the M. officinalis EOs 2 and 3 than in M. officinalis EO 1. These results are in agreement with the findings reported by Seidler-Lozykawska et al., who highlighted significant differences in citral, citronellal, and trans- $\beta$-caryophyllene abundances in the EOs obtained from 22 selected M. officinalis genotypes originating from European botanical gardens [20].

A true quantitation was performed by the external standard calibration to accurately evaluate the abundance of potential bioactive specialized compounds (i.e., neral, geranial, limonene, $\beta$-myrcene, and citronellal. Tables 2 and 3 report the diagnostic ions $(\mathrm{m} / \mathrm{z})$ used for SIM-MS quantitation of the marker compounds under investigation together with the calibration range, the calibration curve equation, correlation values, and regression standard error of each analyte and the quantitation results, respectively.

Table 2. Diagnostic ions $(\mathrm{m} / \mathrm{z})$ used for SIM-MS quantitation of selected marker compounds that characterize the investigated essential oils together with the calibration range, the calibration curve equation, correlation values, and regression standard error.

\begin{tabular}{cccccc}
\hline Compound & Diagnostic Ion & $\begin{array}{c}\text { Calibration Range } \\
(\mathbf{m g} / \mathbf{m L})\end{array}$ & $\begin{array}{c}\text { Calibration Curve } \\
\text { Equation }\end{array}$ & $\begin{array}{c}\text { Correlation } \\
\text { Values }\end{array}$ & $\begin{array}{c}\text { Regression } \\
\text { Standard Error }\end{array}$ \\
\hline Neral & 69 & $0.39-1.95$ & $\mathrm{y}=0.4548 \mathrm{x}+0.0412$ & 0.9983 & 0.01543 \\
Geranial & 69 & $0.61-3.05$ & $\mathrm{y}=0.7701 \mathrm{x}+0.1207$ & 0.9964 & 0.05848 \\
Citral & & $1.00-5.00$ & $\mathrm{y}=0.7067 \mathrm{x}+0.1034$ & 0.9956 & 0.09788 \\
Limonene & 68 & $0.10-2.50$ & $\mathrm{y}=0.6003 \mathrm{x}+0.0828$ & 0.9910 & 0.07348 \\
及-Myrcene & 93 & $0.01-0.08$ & $\mathrm{y}=1.3304 \mathrm{x}-0.0023$ & 0.9994 & 0.001033 \\
Citronellal & 69 & $0.08-4.08$ & $\mathrm{y}=0.5325 \mathrm{x}-0.020$ & 0.9999 & 0.01427 \\
Citronellal & 69 & $0.01-0.08$ & $\mathrm{y}=0.4685 \mathrm{x}-0.0083$ & 1.0000 & 0.0004276 \\
\hline
\end{tabular}

Table 3. Absolute concentrations of potentially bioactive components in the investigated essential oils.

\begin{tabular}{|c|c|c|c|c|c|c|c|c|c|c|c|c|c|}
\hline Essential Oil & Batch & $\begin{array}{c}{[\beta-M y r c e n e]} \\
\quad(g / 100 \mathrm{~g})\end{array}$ & CV & $\begin{array}{c}\text { [Limonene] } \\
(\mathrm{g} / 100 \mathrm{~g})\end{array}$ & $\mathrm{CV}$ & $\begin{array}{c}\text { [Citronellal] } \\
(\mathrm{g} / 100 \mathrm{~g})\end{array}$ & $\mathrm{CV}$ & $\begin{array}{c}\text { [Neral] } \\
(\mathrm{g} / 100 \mathrm{~g})\end{array}$ & $\mathrm{CV}$ & $\begin{array}{c}\text { [Geranial] } \\
(\mathrm{g} / 100 \mathrm{~g})\end{array}$ & $\mathrm{CV}$ & $\begin{array}{l}{[\text { Citral] }} \\
(\mathrm{g} / 100 \mathrm{~g})\end{array}$ & $\mathrm{CV}$ \\
\hline \multirow{3}{*}{ L. cubeba } & 2020 & 0.4 & 5.9 & 14.7 & 1.1 & 1.2 & 0.1 & 24.5 & 2.9 & 34.3 & 3.8 & 59.4 & 3.5 \\
\hline & 2019 & 0.4 & 7.2 & 11.3 & 1.1 & 0.9 & 0.2 & 25.7 & 2.0 & 37.9 & 2.6 & 64.6 & 2.4 \\
\hline & 2018 & 0.3 & 4.8 & 8.8 & 13.4 & 1.7 & 1.0 & 27.7 & 3.5 & 37.5 & 3.6 & 65.6 & 3.5 \\
\hline \multirow{4}{*}{ C. schoenanthus } & 2020 & 0.1 & 8.8 & 2.1 & 3.6 & 0.4 & 0.3 & 25.9 & 1.0 & 37.1 & 1.4 & 63.8 & 1.3 \\
\hline & 2019 & 0.1 & 3.8 & 2.2 & 3.2 & 0.5 & 1.0 & 23.9 & 2.3 & 34.1 & 1.4 & 58.7 & 1.7 \\
\hline & 2018 & 0.1 & 7.5 & 2.4 & 1.5 & 0.4 & 0.7 & 26.7 & 2.7 & 37.8 & 0.9 & 64.8 & 1.4 \\
\hline & 2020 & 0.4 & 5.0 & 10.3 & 2.6 & 5.3 & 0.9 & 21.6 & 3.5 & 28.8 & 3.0 & 50.6 & 3.2 \\
\hline \multirow[t]{2}{*}{ V. officinalis } & 2019 & 0.5 & 1.2 & 16.7 & 4.9 & 4.7 & 2.0 & 16.5 & 3.2 & 24.1 & 2.4 & 41.2 & 2.3 \\
\hline & 2018 & 0.5 & 3.8 & 15.5 & 4.4 & 5.1 & 1.7 & 16.8 & 4.9 & 24.9 & 3.6 & 42.4 & 4.0 \\
\hline \multirow{3}{*}{ M. officinalis } & 1 & 0.0 & 8.9 & 0.0 & - & 0.4 & 4.5 & 15.5 & 0.3 & 22.4 & 0.0 & 36.0 & 0.1 \\
\hline & 2 & 0.1 & 5.2 & 4.3 & 3.1 & 0.4 & 7.7 & 18.4 & 1.2 & 27.7 & 0.4 & 46.9 & 0.5 \\
\hline & 3 & 0.1 & 9.0 & 3.3 & 2.6 & 15.9 & 3.5 & 18.0 & 0.4 & 28.2 & 0.4 & 44.0 & 0.2 \\
\hline
\end{tabular}

\subsection{In Vitro Inhibitory Activity of the Investigated Essential Oils against Mushroom Tyrosinase}

As previously described, the EOs of C. schoenanthus, M. officinalis, L. cubeba, and V. officinalis present high levels of citral, which is characterized by non-competitive inhibitory activity against a fungal source of tyrosinase $[8,16,21]$. This study aimed at examining the in vitro tyrosinase inhibitory activities of these EOs to explore whether their inhibitory activity can be ascribed to their citral content only, or whether there are other bioactive compounds that influence the inhibitory effects of the EOs. 
Mushroom tyrosinase was here adopted because of its high homology to human tyrosinase, its relatively low cost and ready availability, which make it a good model system for the preliminary screening of tyrosinase inhibitors [17]. The precision of the in vitro tyrosinase inhibition test was evaluated in terms of repeatability (by performing the enzymatic inhibition assay five times in the same day) and intermediate precision (by repeating the enzymatic inhibition assay five times every four weeks over a period of six months). Table 4 reports the coefficient of variation (CV) for inhibition tests carried out with kojic acid, which was used as a positive control, and with L. cubeba EO. Results were satisfactory as the CV never exceeded $7 \%$ for repeatability and $10 \%$ for intermediate precision. Table 4 reports the coefficient of variation for inhibition tests carried out with kojic acid, used as positive control, and with L. cubeba EO. Similar precision values were obtained for all the tested EOs.

Table 4. Data precision expressed as CV for both repeatability $(n=5)$ and intermediate precision $(\mathrm{n}=6) .{ }^{*}$ Values represent the average of three assays.

\begin{tabular}{|c|c|c|c|c|}
\hline & \multicolumn{2}{|c|}{ Repeatability $(\mathrm{n}=3)$} & \multicolumn{2}{|c|}{ Intermediate Precision } \\
\hline & $\%$ Inhibition & $\mathrm{CV}$ & $\%$ Inhibition * & $\mathrm{CV}$ \\
\hline \multirow{6}{*}{$\begin{array}{l}\text { Kojic acid } \\
(1.7 \mu \mathrm{g} / \mathrm{mL})\end{array}$} & 64 & \multirow{6}{*}{6} & 59 & \multirow{6}{*}{8} \\
\hline & 58 & & 69 & \\
\hline & 61 & & 67 & \\
\hline & 66 & & 58 & \\
\hline & 64 & & 70 & \\
\hline & & & 66 & \\
\hline \multirow{6}{*}{$\begin{array}{c}\text { Litsea cubeba EO } \\
(166.7 \mu \mathrm{g} / \mathrm{mL})\end{array}$} & 57 & \multirow{6}{*}{7} & 51 & \multirow{6}{*}{11} \\
\hline & 58 & & 59 & \\
\hline & 55 & & 60 & \\
\hline & 62 & & 56 & \\
\hline & \multirow[t]{2}{*}{65} & & 67 & \\
\hline & & & 57 & \\
\hline
\end{tabular}

Citral concentration-response curve was studied by plotting the observed inhibitory activity as a function of its concentration in the reaction mixture. All of the EOs were tested at a concentration of $166.7 \mu \mathrm{g} / \mathrm{mL}$, which provided, irrespective of the EO, a resulting citral concentration within its concentration-response curve linearity range $(y=0.3956 x+1.8094$, $\mathrm{R}^{2}=0.9951$, regression error: 2.08448 , linearity range: $6.7-166.7 \mu \mathrm{g} / \mathrm{mL}$ ) and did not generate solubility issues in the reaction mixture.

The box plot reported in Figure 2 presents the percentage of tyrosinase inhibition for each EO. For L. cubeba, V. officinalis, and C. schoenanthus EOs, the results reported in Figure 2 correspond to the mushroom tyrosinase inhibitory activity of the EOs of 2020 because the analysis of variance revealed no statistically significant differences among EOs of different years of production $(p>0.05)$. In regard to L. cubeba and C. schoenanthus EOs, these outcomes are in good agreement with the results obtained from the quantitative GCMS analyses that revealed an almost identical citral amount in the EOs of different years of production. The batch 2020 of $V$. officinalis EO contains a slightly higher citral amount than the batches 2019 and 2018. However, according to citral concentration-response curve, the citral excess in batch 2020 is not sufficient to determine a statistically significant higher percentage of enzymatic inhibition considering the random error associated with the measurements. For additional details, see Figure S1 in the Supplementary Material. On the other hand, the analysis of variance (ANOVA) followed by Tukey-Kramer post-hoc test revealed that the three tested M. officinalis EOs, provided by distinct manufacturers, inhibited mushroom tyrosinase to different extents, which will be further described in the following paragraphs. The greatest inhibitory activities were observed for the EOs of $L$. cubeba, M. officinalis 1, and V. officinalis, which inhibited $59 \pm 6 \%, 55 \pm 7 \%$, and $52 \pm 6 \%$ of tyrosinase activity, respectively, when tested at a concentration of $166.7 \mu \mathrm{g} / \mathrm{mL}$. Statistically 
significant $(p<0.05)$ lower activities were observed for the EOs of $C$. schoenanthus and $M$. officinalis 2 and 3 whose enzyme inhibitory activity was $42 \pm 5 \%, 40 \pm 5 \%$, and $38 \pm 6 \%$, respectively. Table 5 provides the inhibitor concentration that halved the enzyme activity in the given experimental conditions $\left(\mathrm{IC}_{50}\right)$ for each investigated inhibitor (i.e., EOs, single compounds, and kojic acid). All of the EOs effectively inhibited mushroom tyrosinase and displayed an inhibitory activity that was, on average, 100-times lower than that of kojic acid, which was used as the positive control.

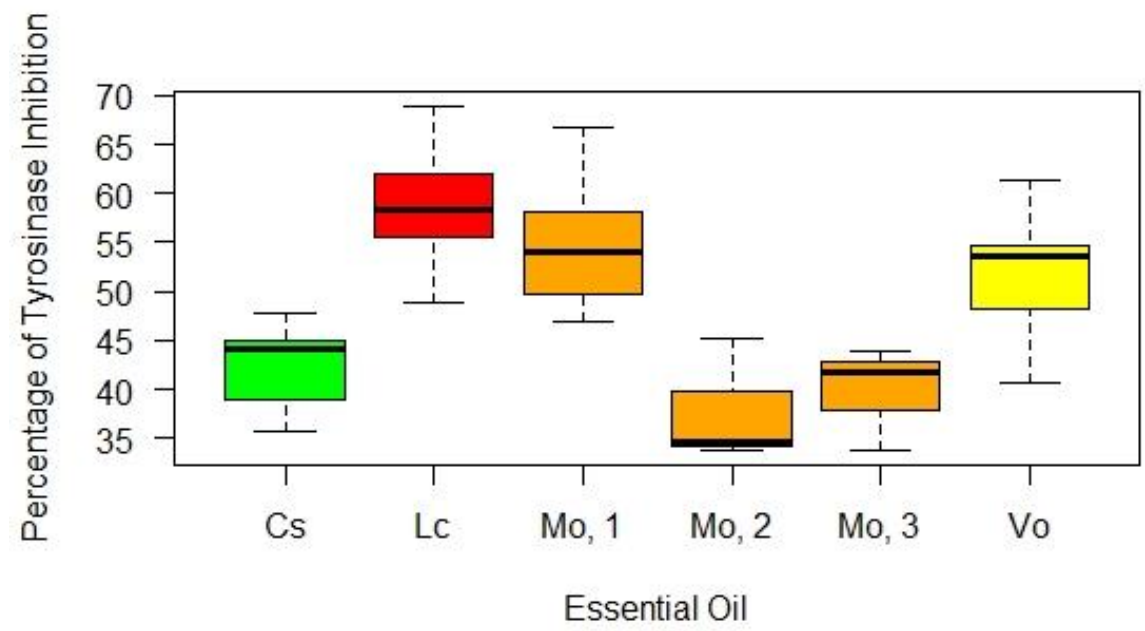

Figure 2. Percentage of tyrosinase inhibition for each investigated EO tested at a concentration of $166.7 \mu \mathrm{g} / \mathrm{mL}$. Legend: Cs: Cymbopogon schoenanthus (batch 2020); Lc: Litsea cubeba (batch 2020); Mo,1: Melissa officinalis 1; Mo,2: Melissa officinalis 2; Mo,3: Melissa officinalis 3; Vo: Verbena officinalis (bacth 2020).

Table 5. $\mathrm{IC}_{50}$ values of each investigated essential oil and of some bioactive components together with their relative standard deviation value.

\begin{tabular}{cc}
\hline Inhibitor & IC $_{\mathbf{5 0}}(\boldsymbol{\mu g} / \mathbf{m L})$ \\
\hline Kojic acid & $1.0 \pm 0.4$ \\
Citral & $121.8 \pm 13.7$ \\
B-Myrcene & $13.3 \pm 3.1$ \\
C. schoenanthus EO & $216.7 \pm 18.3$ \\
L. cubeba EO & $125.0 \pm 16.5$ \\
M. officinalis EO 1 & $152.2 \pm 21.1$ \\
M. officinalis EO 2 & $220.1 \pm 27.7$ \\
M. officinalis EO 3 & $209.2 \pm 22.5$ \\
V. officinalis EO & $167.0 \pm 19.1$ \\
\hline
\end{tabular}

\subsection{Identification of Additional Bioactive Components, Besides Citral, by Bioassay-Guided Fractionation}

The histogram reported in Figure 3 compares the percentage of experimentally measured enzymatic inhibitions to the values that would be expected if neral and geranial (considered as sum, i.e., citral) were the only active compounds in the investigated EOs. These values were measured via interpolation from the citral concentration-response curve. As can be noted, C. schoenanthus, M. officinalis 2, and M. officinalis 3 displayed inhibitory activities that were in-line with their citral content, while L. cubeba, M. officinalis 1, and $V$. officinalis EOs inhibited mushroom tyrosinase to a greater extent than expected.

A bio-guided approach was adopted to identify the additional compounds that contribute to citral activity. The oxygenated and hydrocarbon fractions of the L. cubeba, M. officinalis 1, and V. officinalis EOs were isolated by flash chromatography and individually tested for their mushroom tyrosinase inhibitory activities. The fractions phytohemical compositions are reported in the Supplementary Materials (Tables S1-S5). The isolated 
fractions were tested at the same concentration as their resulting concentration when testing $166.7 \mu \mathrm{g} / \mathrm{mL}$ of the respective EO (see Materials and Methods section at Section 3.2). Table 6 reports the concentration of neral, geranial, citronellal, limonene, and $\beta$-myrcene in the oxygenated and hydrocarbon fractions of the fractionated EOs.

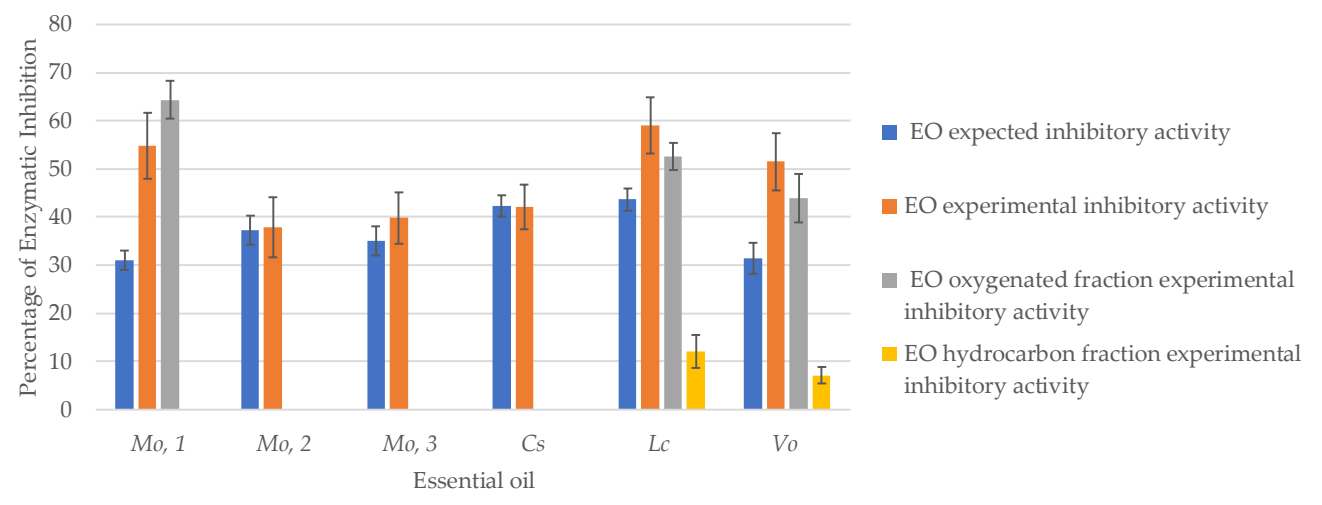

Figure 3. Comparison of the percentage of experimentally measured enzymatic inhibition and the enzymatic inhibition expected with citral as the only bioactive compound in the essential oils. Legend: Cs: Cymbopogon schoenanthus (batch 2020); Lc: Litsea cubeba (batch 2020); Mo,1: Melissa officinalis 1; Mo,2: Melissa officinalis 2; Mo3: Melissa officinalis 3; Vo: Verbena officinalis (batch 2020).

Table 6. Concentration of selected bioactive compounds in the oxygenated and hydrocarbon fractions of the fractionated essential oils.

\begin{tabular}{|c|c|c|c|c|c|c|c|c|c|c|c|c|}
\hline & $\begin{array}{c}\text { [3-Mycene] } \\
\text { (g/100 g) }\end{array}$ & $\mathrm{CV}$ & $\begin{array}{c}\text { [Limonene] } \\
(\mathrm{g} / 100 \mathrm{~g})\end{array}$ & CV & $\begin{array}{c}\text { [Citronellal] } \\
\text { (g/100 g) }\end{array}$ & CV & $\begin{array}{c}\text { [Neral] } \\
\text { (g/100 g) }\end{array}$ & $\mathrm{CV}$ & $\begin{array}{c}\text { [Geranial] } \\
(\mathrm{g} / 100 \mathrm{~g})\end{array}$ & $\mathrm{CV}$ & $\begin{array}{c}\text { [Citral] } \\
\text { (g/100 g) }\end{array}$ & $\mathrm{CV}$ \\
\hline $\begin{array}{c}\text { L. cubeba } \\
\text { hydrocarbon fraction }\end{array}$ & 1.4 & 0.3 & 59.4 & 6.0 & & & & & & & & \\
\hline $\begin{array}{l}\text { L. cubeba } \\
\text { oxygenated fraction }\end{array}$ & & & & & 1.0 & 1.5 & 42.2 & 0.1 & 53.2 & 0.5 & 94.8 & 0.3 \\
\hline $\begin{array}{l}\text { V. officinalis } \\
\text { hydrocarbon fraction }\end{array}$ & 1.8 & 0.2 & 47.2 & 0.8 & & & & & & & & \\
\hline $\begin{array}{c}\text { V. officinalis } \\
\text { oxygenated fraction } \\
\text { M. officinalis, } 1 \\
\text { hydrocarbon fraction }\end{array}$ & & & & & 2.0 & 2.8 & 35.1 & 0.6 & 42.3 & 0.2 & 76.9 & 0.3 \\
\hline $\begin{array}{l}\text { M. officinalis, } 1 \\
\text { oxygenated fraction }\end{array}$ & & & & & 14.1 & 0.4 & 18.6 & 0.3 & 26.7 & 0.4 & 44.8 & 0.4 \\
\hline
\end{tabular}

As for L. cubeba and V. officinalis EOs, both the oxygenated and hydrocarbon fractions inhibited mushroom tyrosinase, although to different extents. The activities of the oxygenated fractions (53 $\pm 3 \%$ and $44 \pm 5$, respectively) account for most of the EOs anti-tyrosinase potential and were in-line with the respective citral content, suggesting that the compounds that contribute to citral activity belong to the hydrocarbon fractions. The hydrocarbon fractions of the L. cubeba and V. officinalis EOs present quite similar chemical compositions. Limonene (68.4 and 50.3\%, respectively), trans- $\beta$-caryophyllene (12.0 and $7.8 \%$, respectively), $\alpha$-pinene (1.7 and 7.5\%, respectively), $\beta$-pinene ( 2.5 and $12.9 \%$, respectively), sabinene (2.7 and 3.8, respectively), and $\beta$-myrcene ( 2.0 and $2.4 \%$, respectively) are the most abundant compounds in both fractions and are present in rather similar amounts, except for $\alpha$-pinene and $\beta$-pinene, which prevail in the $V$. officinalis EO hydrocarbon fraction.

The chiral recognition revealed high enantiomeric purities in favor of the (-)-configured enantiomers for trans- $\beta$-caryophyllene ( $>99 \%$ in both EOs), limonene (97 and $94 \%$ in $L$. cubeba and $V$. officinalis EO, respectively) and sabinene (87\% in both EOs), while different enantiomeric excesses were observed for $\alpha$-pinene ((-)-enantiomer: $38 \%$ in L. cubeba $\mathrm{EO}$ and $73 \%$ in V. officinalis EO) and $\beta$-pinene ((-)-enantiomer: 67\% in L. cubeba EO and 88\% in $V$. officinalis EO). In both EOs, (-)-limonene accounts for more than 50\% of the entire fraction. However, although previous studies have reported an inhibitory activity against 
mushroom tyrosinase because of its high abundance [22,23], (-)-limonene here did not show a tyrosinase inhibitory activity. Similar results were obtained for (+)-limonene, the racemic mixture, and the compounds (-)-trans- $\beta$-caryophyllene, $( \pm)$ - $\alpha$-pinene, and $( \pm)$ - $\beta$-pinene. Sabinene was not tested as it had already been proven to have negligible mushroom tyrosinase inhibitory effects [8]. In agreement with previous findings [8], $\beta$ myrcene reduced mushroom tyrosinase activity. When tested at the concentration observed in $166.7 \mu \mathrm{g} / \mathrm{mL}$ of L. cubeba and $V$. officinalis EOs, $\beta$-myrcene activity bridged the gap between the EOs' expected inhibitory effects if citral was the only active compound and the experimental results. Contrary to the observations by Matsuura et al. [8], $\beta$-myrcene proved to be a more potent mushroom tyrosinase inhibitor than citral, as its $\mathrm{IC}_{50}$ was almost ten times lower $(13.3 \mu \mathrm{g} / \mathrm{mL}$ vs. $121.8 \mu \mathrm{g} / \mathrm{mL})$. This difference may be ascribed to the different substrates used; Matsuura et al. investigated mushroom tyrosinase diphenolase activity only, as they used L-DOPA as the substrate, whereas, in this study, L-tyrosine was used. The current findings suggest that $\beta$-myrcene may be more effective at inhibiting mushroom tyrosinase monophenolase activity than the diphenolase one.

The M. officinalis EO 1 displays a small hydrocarbon fraction that accounts for less than $3 \%$ of the total, and has no tyrosinase inhibitory activity. However, the M. officinalis EO 1 oxygenated fraction inhibited mushroom tyrosinase to a greater extent than would be expected from its citral content (Figure 3). This fraction contains significant amounts of citronellal in addition to neral and geranial and the chiral analysis revealed a high enantiomeric purity of citronellal in favor of the (+) enantiomer (98.3\%). When tested independently, at a concentration of $166.7 \mu \mathrm{g} / \mathrm{mL},(+)$-citronellal inhibited mushroom tyrosinase to a negligible extent, although its activity was significantly enhanced when tested in combination with citral. These results may explain the differences observed in the percentages of mushroom tyrosinase inhibition in the various $M$. officinalis EOs. $M$. officinalis EO 2 and 3 present very low citronellal contents, which may be the reason why their inhibitory activities are significantly lower than that of M. officinalis EO 1.

\section{Materials and Methods}

\subsection{Reagents}

Dimethyl sulfoxide (DMSO), mushroom tyrosinase from Agaricus bisporus (J.E. Lange) Imbach, L-tyrosine, kojic acid, citral, citronellal, $\beta$-myrcene, (+)-limonene, (-)-limonene, $( \pm$ )-limonene, $( \pm)-\alpha$, and $\beta$ pinene were purchased from Merck Life Science S.r.l. (Milan, Italy). Litsea cubeba, Verbena officinalis, and Cymbopogon schoenanthus EOs were supplied by Erboristeria Magentina S.r.l. (Poirino, Italy). Three batches of different years (i.e., 2020, 2019 , 2018) were tested for each. Three samples of Melissa officinalis EOs were investigated; one was provided by Agronatura (Spigno Monferrato, Alessandria), one by Erboristeria Magentina S.r.l., while the last was purchased from a local shop and was from Specchiasol S.r.l. (Bussolengo, Italy). In the text, the authors refer to the different EOs of Melissa officinalis as M. officinalis EOs 1, 2, and 3, respectively. The provided EOs were obtained following the procedures described in the European Pharmacopoeia [24]. Melissa officinalis and Verbena officinalis EOs were produced by hydrodistillation from the leaves and plants aerial parts, respectively; similarly, Litsea cubeba and Cymbopogon schoenanthus EOs were obtained by steam distillation of the fresh fruits and fresh aerial parts, respectively. Each EO was individually analyzed by GC-MS as soon as it was purchased/provided by the corresponding manufacturer, every storage year, and just before the study of its mushroom tyrosinase inhibitory activity.

\subsection{In Vitro Tyrosinase Inhibitory Assay}

The tyrosinase inhibitory activities of the EOs and isolated compounds were investigated in vitro using a colorimetric readout-based enzyme assay optimized by Zengh et al. [25], with slight modifications. The tyrosinase inhibitory activities of EOs, as well as their respective hydrocarbon and oxygenated fractions and pure compounds were investigated in vitro using a colorimetric readout-based enzyme assay that was optimized by Zengh et al. [25], 
with slight modifications: the assay was carried out at room temperature and tyrosinase inhibition was measured considering control and sample absorbance after 6 min of incubation, rather than after $20 \mathrm{~min}$, so as to operate under the linear portion of the enzymatic reaction, which provides more accurate inhibition results [26,27]. Mushroom tyrosinase from Agaricus bisporus (J.E. Lange) Imbach was selected for this study. L-Tyrosine was used as the substrate, meaning that the overall tyrosinase inhibitory activity was investigated without distinguishing between tyrosinase monophenolase and diphenolase activity. Photometric measurements at $475 \mathrm{~nm}$ were performed on a Thermo spectronic Genesys 6 and kojic acid was used as the positive control inhibitor. The solutions of the investigated potential inhibitors (EOs, EO isolated fractions, EO individual compounds, and kojic acid) were prepared in DMSO. Table 7 reports the tested concentrations for each investigated potential inhibitor. The mushroom tyrosinase solution $200 \mathrm{U} / \mathrm{mL}(27.9 \mu \mathrm{g} / \mathrm{mL})$ was prepared in sodium phosphate buffer $(\mathrm{pH}$ 6.8) and aliquots of $9 \mathrm{~mL}$ were stored at $-18{ }^{\circ} \mathrm{C}$ and thawed just before the experiments. Tyrosine solution $0.1 \mathrm{mg} / \mathrm{mL}$ was prepared in sodium phosphate buffer ( $\mathrm{pH}$ 6.8) and renewed daily. The reaction mixture components were placed in the vial in the following order: $1 \mathrm{~mL}$ of mushroom tyrosinase solution $200 \mathrm{U} / \mathrm{mL} ; 1 \mathrm{~mL}$ of sodium phosphate buffer solution; $10 \mu \mathrm{L}$ of EO/single compound/kojic acid solution; and, finally, $1 \mathrm{~mL}$ of tyrosine solution $0.1 \mathrm{mg} / \mathrm{mL}$. The final DMSO percentage in the reaction mixture was $0.3 \%$. The assay was performed in a sealed $4 \mathrm{~mL}$ vial to avoid the loss of any EO components into the surrounding environment and to minimize their release into the head space above the reaction mixture. The reaction mixture was incubated in a thermostatic water bath at $25^{\circ} \mathrm{C}$ for $6 \mathrm{~min}$. Subsequently, the absorbance at $475 \mathrm{~nm}$ was registered, as this wavelength allows the identification of dopachrome. The absorbance corresponding to $100 \%$ of tyrosinase activity was measured by replacing the EOs/individual compound/kojic acid solution with $10 \mu \mathrm{L}$ of pure DMSO. Blank solutions were prepared as follows: $2 \mathrm{~mL}$ of sodium phosphate buffer solution, $10 \mu \mathrm{L}$ of EO/individual compound/kojic acid/DMSO solution, and $1 \mathrm{~mL}$ of tyrosine solution $0.1 \mathrm{mg} / \mathrm{mL}$. The percentage of tyrosinase inhibition was measured according to the equation below:

$$
\% \text { Inhibition }=\Delta \mathrm{A}(\text { Control })-\Delta \mathrm{A}(\text { Sample }) / \Delta \mathrm{A}(\text { Control }) \times 100,
$$

$\Delta \mathrm{A}\left(\right.$ Control) or (Sample) $=\mathrm{A}_{475}$ (Control) or (Sample) $-\mathrm{A}_{475}$ (Control Blank) or (Sample Blank).

Table 7. Tested concentrations for investigated essential oils and for both the relative isolated hydrocarbon and oxygenated fractions.

\begin{tabular}{|c|c|c|}
\hline Tested Sample & [Stock Solution] (mg/mL) & $\begin{array}{c}\text { [Sample] Reaction Mixture } \\
(\mu \mathrm{g} / \mathrm{mL})\end{array}$ \\
\hline L. cubeba EO & $5.0-50.0$ & $16.7-166.7$ \\
\hline L. cubeba EO oxygenated fraction & 40.0 & 133.3 \\
\hline L. cubeba EO hydrocarbon fraction & 10.0 & 33.3 \\
\hline V. officinalis EO & $5.0-50.0$ & $16.7-166.7$ \\
\hline V. officinalis EO oxygenated fraction & 40.0 & 133.3 \\
\hline V. officinalis EO hydrocarbon fraction & 10.0 & 33.3 \\
\hline C. schoenanthus EO & $5.0-50.0$ & $16.7-166.7$ \\
\hline M. officinalis EO 1 & $5.0-50.0$ & 166.7 \\
\hline M. officinalis EO 1 oxygenated fraction & 48.0 & 160.0 \\
\hline M. officinalis EO 1 hydrocarbon fraction & 2.0 & 6.7 \\
\hline M. officinalis EO 2 & $5.0-50.0$ & $16.7-166.7$ \\
\hline M. officinalis EO 3 & $5.0-50.0$ & $16.7-166.7$ \\
\hline Citral & $3.0-50.0$ & $10-166.7$ \\
\hline (+)-Citronellal & $10.0,50.0$ & $33.3,166.7$ \\
\hline
\end{tabular}


Table 7. Cont.

\begin{tabular}{ccc}
\hline Tested Sample & [Stock Solution] (mg/mL) & $\begin{array}{c}\text { [Sample] Reaction Mixture } \\
(\mu \mathrm{g} / \mathrm{mL})\end{array}$ \\
\hline Citral $+(+)$-Citronellal & $20.0+10.0$ & $66.7+33.3$ \\
\hline$\beta$-Myrcene & $0.1-10.0$ & $0.3-33.3$ \\
\hline$(-)$-trans- $\beta$-caryophyllene & 20.0 & 66.7 \\
\hline$(+)$-Limonene & 10.0 & 33.3 \\
\hline$(-)$-Limonene & 10.0 & 33.3 \\
\hline$( \pm)$-Limonene & 10.0 & 33.3 \\
\hline$( \pm)$ - $\alpha$-Pinene & 2.0 & 6.7 \\
\hline$( \pm)$ - $\beta$-Pinene & 2.0 & 6.7 \\
\hline kojic acid & $0.02-0.2$ & $0.067-0.67$ \\
\hline
\end{tabular}

Determination of Concentration-Response Curve and $\mathrm{IC}_{50}$ for Inhibitors

The concentration-response curve for each inhibitor was determined by plotting the inhibitory activity as a function of inhibitor concentration in the reaction mixture. $\mathrm{IC}_{50}$ values for the inhibitors were obtained by interpolation from the concentrationresponse curve.

\subsection{Flash Column Chromatography}

EO fractionation was carried out on a flash column chromatography system PuriFlash 450 by Sepachrom (Rho, Milan, Italy), equipped with both UV and ELSD detectors. The amount of EO fractionated: $900.0 \mathrm{mg}$. Stationary phase: spherical silica gel particles, $50 \mu \mathrm{m}, 25 \mathrm{mg}$ (Purezza ${ }^{\circledR}$-Sphera Cartridge Stationary) was from Sepachrom; mobile phase: petrolether (A) and ethyl acetate (B); flow-rate $25 \mathrm{~mL} / \mathrm{min}$. Linear gradient elution was adopted from $100 \%$ of $\mathrm{A}$ to $80 \%$ of $\mathrm{A}$ and $20 \%$ of B over 20 min.

\subsection{Analysis Conditions}

The EOs solutions and those of their respective fractions were prepared in cyclohexane at a concentration of $5.0 \mathrm{mg} / \mathrm{mL}$ and analyzed by GC-MS. Citral, citronellal, $\beta$-myrcene, and limonene were quantified in each EO and the corresponding isolated fractions using the external standard calibration method. Suitable calibration levels were prepared in cyclohexane and analyzed by GC-MS. Tridecane (C13) $1.0 \mathrm{mg} / \mathrm{mL}$ was used as the internal standard to normalize the analyte signals. Table 2 summarizes the considered concentration range for each quantified compound.

GC-MS analyses were carried out using a Gerstel MPS-2 multipurpose sampler (Mülheim an der Ruhr, Germany) installed on an Agilent 6890 N GC coupled to a 5975 MSD and equipped with a ChemStation Version E.02.02.1431 data processing system (Agilent Technologies, Santa Clara, CA, USA). GC conditions: injector temperature: $250^{\circ} \mathrm{C}$; injection mode: split; ratio: 1/20; carrier gas: helium; constant flow rate: $1 \mathrm{~mL} / \mathrm{min}$; columns: Mega 5 (95\% polydimethylsiloxane, $5 \%$ phenyl) df $0.25 \mu \mathrm{m}$, dc $0.25 \mathrm{~mm}$, length $25 \mathrm{~m}$, from MEGA (Legnano, Italy). Temperature program: $50{ }^{\circ} \mathrm{C} / / 3{ }^{\circ} \mathrm{C} / \mathrm{min} / / 180{ }^{\circ} \mathrm{C} / / 10{ }^{\circ} \mathrm{C} / \mathrm{min} / / 250{ }^{\circ} \mathrm{C}$ (5 min). MSD conditions: MS operated in EI mode (70 eV); scan range: 35 to $350 \mathrm{amu}$; dwell time $40 \mathrm{~ms}$; ion source temperature: $230{ }^{\circ} \mathrm{C}$; quadrupole temperature: $150{ }^{\circ} \mathrm{C}$; transferline temperature: $280^{\circ} \mathrm{C}$. EO markers were identified by comparing both their linear retention indices (ITs), calculated versus a C9-C25 hydrocarbon mixture, and their mass spectra either against those of authentic samples, or from commercially available mass spectral libraries (Adams, 2007). EO chiral analyses were performed by adopting the same analysis conditions on a 2,3-di-O-methyl-6-O-t-butyldimethylsilyl- $\beta$-CD (2,3DM6TBDMS$\beta$-CD) df $0.25 \mu \mathrm{m}$, dc $0.25 \mathrm{~mm}$, length $25 \mathrm{~m}$ from MEGA. Temperature programs: $40{ }^{\circ} \mathrm{C}$ $(1 \mathrm{~min}) / / 2{ }^{\circ} \mathrm{C} / \mathrm{min} / / 220^{\circ} \mathrm{C}(5 \mathrm{~min})$. 
GC-FID analyses were carried out on the same instrument. GC conditions: injector temperature: $250{ }^{\circ} \mathrm{C}$; injection mode: split; ratio: $1 / 20$; carrier gas: hydrogen; flow rate: $1 \mathrm{~mL} / \mathrm{min}$. Temperature programs: $40{ }^{\circ} \mathrm{C}(1 \mathrm{~min}) / / 2{ }^{\circ} \mathrm{C} / \mathrm{min} / / 220^{\circ} \mathrm{C}(5 \mathrm{~min})$.

\section{Conclusions}

The purposes of this investigation were (1) to examine comprehensively the in vitro mushroom tyrosinase inhibitory activities of the Cymbopogon schoenanthus, Litsea cubeba, Melissa officinalis, and Verbena officinalis EOs and (2) to determine whether their biological activity is ascribed to their citral content only or if there are additional bioactive monoterpenes that contribute to the investigated biological activity by using a bioassay-guided fractionation approach. This study has identified that in L. cubeba and V. officinalis EOs, the $\beta$-myrcene contributes to the EOs inhibitory activities despite its little amount and it has been shown to have a greater inhibitory power to citral. The second major finding was that (+)-citronellal enhanced citral mushroom tyrosinase inhibitory power, potentially via synergistic interaction as it displayed no activity on its own. The latter finding explained why in M. officinalis EOs that bear negligible (+)-citronellal amounts, the inhibitory activities were in-line with their citral content while the contrary was true for the M. officinalis EO with relatively high (+)-citronellal abundance.

Even though further studies are still required to accurately define the type of interactions that occur in between $\beta$-myrcene and citral and in between citronellal and citral, and to assess the inhibitory activities of these EOs and individual compounds on human tyrosinase, the results of this study may help to rationally design mixtures of EOs or enriched EOs that improve their biological efficacy and increase their potential as adjuvants in the treatment of hyperpigmentation.

Supplementary Materials: The following are available online at https:/ /www.mdpi.com/article/10 .3390/plants10050969/s1: Tables S1-S5: total chemical composition (expressed as normalized relative percentage area of each identified compound of the investigated essential oils).

Author Contributions: Conceptualization, B.S. and F.C.; methodology, F.C. and B.S.; investigation, F.C., M.T., A.M.; data curation, F.C., M.T., C.C.; writing-original draft preparation, F.C.; writingreview and editing, B.S., C.B., C.C., P.R.; supervision, B.S. All authors have read and agreed to the published version of the manuscript.

Funding: This study was carried out within the project "Studio di composti biologicamente attivi del metabolismo secondario di matrici di origine vegetale" financially supported by 'Ricerca Locale' (Ex60\%2020) of University of Turin, Turin (Italy).

Institutional Review Board Statement: Not applicable.

Informed Consent Statement: Not applicable.

Data Availability Statement: All figures and tables in this manuscript are original and unpublished anywhere else.

Acknowledgments: The authors are indebted to Gloria Giussani and Erboristeria Magentina for supplying the essential oils.

Conflicts of Interest: The authors declare no conflict of interest.

\section{Abbreviations}

$\begin{array}{ll}\text { EO } & \text { Essential Oil } \\ \text { GC-MS } & \text { Gas Chromatography-Mass Spectrometry } \\ \text { FID } & \text { Flame Ionization Detector } \\ \text { SIM } & \text { Single Ion Monitoring } \\ \text { CV } & \text { Coefficient of Variation }\end{array}$




\section{References}

1. Pillaiyar, T.; Manickam, M.; Namasivayam, V. Skin whitening agents: Medicinal chemistry perspective of tyrosinase inhibitors. J. Enzym. Inhib. Med. Chem. 2017, 32, 403-425. [CrossRef]

2. Desmedt, B.; Courselle, P.; De Beer, J.O.; Rogiers, V.; Grosber, M.; Deconinck, E.; De Paepe, K. Overview of skin whitening agents with an insight into the illegal cosmetic market in Europe. J. Eur. Acad. Dermatol. Venereol. 2016, 30, 943-950. [CrossRef] [PubMed]

3. Desmedt, B.; Van Hoeck, E.; Rogiers, V.; Courselle, P.; De Beer, J.O.; De Paepe, K.; Deconinck, E. Characterization of suspected illegal skin whitening cosmetics. J. Pharm. Biomed. Anal. 2014, 90, 85-91. [CrossRef] [PubMed]

4. Kubo, I.; Ikuyo, K.H. Flavonols from saffron flower: Tyrosinase inhibitory activity and inhibition mechanism. J. Agric. Food Chem. 1999, 47, 4121-4125. [CrossRef]

5. Chang, C.-T.T.; Chang, W.-L.L.; Hsu, J.-C.C.; Shih, Y.; Chou, S.-T.T. Chemical composition and tyrosinase inhibitory activity of Cinnamomum cassia essential oil. Bot. Stud. 2013, 54, 2-8. [CrossRef]

6. Garcia-Molina, M.D.M.; Muñoz-Muñoz, J.L.; Garcia-Molina, F.; García-Ruiz, P.A.; Garcia-Canovas, F. Action of tyrosinase on ortho-substituted phenols: Possible influence on browning and melanogenesis. J. Agric. Food Chem. 2012, 60, 6447-6453. [CrossRef]

7. Kubo, I.; Kinst-Hori, I. Tyrosinase Inhibitors from Cumin. J. Agric. Food Chem. 1998, 46, 5338-5341. [CrossRef]

8. Matsuura, R.; Ukeda, H.; Sawamura, M. Tyrosinase inhibitory activity of citrus essential oils. J. Agric. Food Chem. 2006, 54, 2309-2313. [CrossRef]

9. Lertsatitthanakorn, P.; Taweechaisupapong, S.; Aromdee, C.; Khunkitti, W. In vitro bioactivities of essential oils used for acne control. Int. J. Aromather. 2006, 16, 43-49. [CrossRef]

10. Bouzenna, H.; Hfaiedh, N.; Giroux-Metges, M.-A.; Elfeki, A.; Talarmin, H. Biological properties of citral and its potential protective effects against cytotoxicity caused by aspirin in the IEC-6 cells. Biomed. Pharmacother. 2017, 87, 653-660. [CrossRef]

11. Lee, H.J.; Jeong, H.S.; Kim, D.J.; Noh, Y.H.; Yuk, D.Y.; Hong, J.T. Inhibitory effect of citral on NO production by suppression of iNOS expression and NF-kB activation in RAW264.7 cells. Arch. Pharm. Res. 2008, 31, 342-349. [CrossRef]

12. Carvalho, P.M.M.; Macêdo, C.A.F.; Ribeiro, T.F.; Silva, A.A.; Da Silva, R.E.R.; de Morais, L.P.; Kerntopf, M.R.; Menezes, I.R.A.; Barbosa, R. Effect of the Lippia alba (Mill.) N.E. Brown essential oil and its main constituents, citral and limonene, on the tracheal smooth muscle of rats. Biotechnol. Rep. 2018, 17, 31-34. [CrossRef] [PubMed]

13. Pereira-de-Morais, L.; Silva, A.d.A.; da Silva, R.E.R.; Costa, R.H.S.d.; Monteiro, Á.B.; Barbosa, C.R.d.S.; Amorim, T.d.S.; de Menezes, I.R.A.; Kerntopf, M.R.; Barbosa, R. Tocolytic activity of the Lippia alba essential oil and its major constituents, citral and limonene, on the isolated uterus of rats. Chem. Biol. Interact. 2019, 297, 155-159. [CrossRef]

14. Da Silva, R.E.R.; de Morais, L.P.; Silva, A.A.; Bastos, C.M.S.; Pereira-Gonçalves, Á.; Kerntopf, M.R.; Menezes, I.R.A.; Leal-Cardoso, J.H.; Barbosa, R. Vasorelaxant effect of the Lippia alba essential oil and its major constituent, citral, on the contractility of isolated rat aorta. Biomed. Pharmacother. 2018, 108, 792-798. [CrossRef] [PubMed]

15. Sousa, D.G.; Sousa, S.D.G.; Silva, R.E.R.; Silva-Alves, K.S.; Ferreira-da-Silva, F.W.; Kerntopf, M.R.; Menezes, I.R.A.; Leal-Cardoso, J.H.; Barbosa, R. Essential oil of Lippia alba and its main constituent citral block the excitability of rat sciatic nerves. Braz. J. Med. Biol. Res. 2015, 48, 697-702. [CrossRef] [PubMed]

16. Huang, X.-W.; Feng, Y.-C.; Huang, Y.; Li, H.-L. Potential cosmetic application of essential oil extracted from Litsea cubeba fruits from China. J. Essent. Oil Res. 2013, 25, 112-119. [CrossRef]

17. Zolghadri, S.; Bahrami, A.; Hassan Khan, M.T.; Munoz-Munoz, J.; Garcia-Molina, F.; Garcia-Canovas, F.; Saboury, A.A. A comprehensive review on tyrosinase inhibitors. J. Enzym. Inhib. Med. Chem. 2019, 34, 279-309. [CrossRef]

18. Bicchi, C.; Liberto, E.; Matteodo, M.; Sgorbini, B.; Mondello, L.; Zellner, B.d.; Costa, R.; Rubiolo, P. Quantitative analysis of essential oils: A complex task. Flavour Fragr. J. 2008, 23, 382-391. [CrossRef]

19. Rubiolo, P.; Sgorbini, B.; Liberto, E.; Cordero, C.; Bicchi, C. Essential oils and volatiles: Sample preparation and analysis. A review. Flavour Fragr. J. 2010, 25, 282-290. [CrossRef]

20. Seidler-Łozykowska, K.; Bocianowski, J.; Król, D. The evaluation of the variability of morphological and chemical traits of the selected lemon balm (Melissa officinalis L.) genotypes. Ind. Crops Prod. 2013, 49, 515-520. [CrossRef]

21. Kubo, I.; Kinst-Hori, I. Tyrosinase inhibitory activity of the olive oil flavor compounds. J. Agric. Food Chem. 1999, 47, 4574-4578. [CrossRef] [PubMed]

22. Fiocco, D.; Arciuli, M.; Arena, M.P.; Benvenuti, S.; Gallone, A. Chemical composition and the anti-melanogenic potential of different essential oils. Flavour Fragr. J. 2016, 31, 255-261. [CrossRef]

23. Hu, J.J.; Li, X.; Liu, X.H.; Zhang, W.P. Inhibitory effect of lemon essential oil on mushroom tyrosinase activity in vitro. Mod. Food Sci. Technol. 2015, 31, 97-105. [CrossRef]

24. Council of Europe. European Pharmacopoeia, 10th ed.; Council of Europe: Strasburg, France, 2020; ISBN 978-92-871-8921-9.

25. Zheng, Z.P.; Tan, H.Y.; Chen, J.; Wang, M. Characterization of tyrosinase inhibitors in the twigs of Cudrania tricuspidata and their structure-activity relationship study. Fitoterapia 2013, 84, 242-247. [CrossRef] [PubMed]

26. Williams, K.P.; Scott, J.E. Enzyme Assay Design for High-Throughput Screening. In High Throughput Screening. Methods in Molecular Biology (Methods and Protocols); Janzen, W.P., Paul, B., Eds.; Humana Press: Clifton, NJ, USA, 2009; Volume 565, pp. 107-126.

27. Brooks, H.B.; Geeganage, S.; Kahl, S.D.; Montrose, C.; Sittampalam, S.; Smith, M.C.; Weidner, J.R. Basics of Enzymatic Assays for HTS. In Assay Guidance Manual; Markossian, S., Sittampalam, S., Grossman, A., Eds.; Eli Lilly \& Company and the National Center for Advancing Translational Sciences: Bethesda, MD, USA, 2004. 